\title{
OLEXANDER GNILITSKY ON THE "NEW WAVE”: ARTIST IN THE LATE 1980s THROUGH EARLY 1990s
}

\author{
IGOR ABRAMOVYCH
}

\begin{abstract}
The early stage of creativity of Ukrainian artist Olexander Gnilitsky (1961-2009) has been studied in the article. It is shown that his works should be viewed in close connection with the historical and everyday context, taking into account the circumstances, time, social and creative environment. It is noted that the early stage of creativity, and eventually the final formation of Gnilitsky as an artist, took place at crucial times in the history of Ukraine-when the established canons of painting prescribed by the Soviet Totalitarian regime proved to be archaic and were subjected to shattering doubt by the younger generation of artists. It is emphasized that Gnilitsky's works of the period are characterized with subjectivism, citations, self-irony, cynical rethinking of literary subjects, the use of grotesque techniques, motifs of macabre eroticism. On the material selected for processing, a historical and cultural analysis was carried out in the context of the formation of Ukrainian art in the late 1980s and early 1990s, where the artist's personality seems particularly relevant, since it symbolizes the specificity of this art: from surprise to shock, from complexity to grotesque, from incorruptibility to despair and even blasphemy. An attempt is made to show all the genuine, heroic sacrifice of a true master. This is particularly eloquent in relation to contemporary art, whose fundamental self-appraisal is fixated in the judgments and statements of its representatives. The general picture of Gnilitsky's life and work, his personality fit perfectly into the ideal or, rather, the norm of the "avant-garde", with both its artistic and philosophical definitions. Analysis of the artist's works shows, in particular, his creative formation in the context of the "New Wave" movement and the "Paris Commune" group.

Keywords: Art of Ukraine of the 1980s-1990s, art of Olexander Gnilitsky, "New Wave”, "Paris Commune” group, painting, installation.
\end{abstract}

Problem statement. Main purpose of the current outline is to study the first stage of Oleksander Gnilitsky's (1961-2009) work. Gnilitsky was a brilliant exponent of the "New Wave" movement that started contemporary era in the history of Ukrainian art.

In general, Gnilitsky's oeuvre emphasizes and reveals the inner specifics of the "New Wave": the movement that in a paradoxical yet edifying way managed, from the one hand, to correspond fully with the global perspective of the newest art, contemporary trends and events; from the other hand, in an equally vivid and peremptory manner, proved loyalty to its roots - to art, truly Ukrainian in all its national traits and unprejudiced conclusions.
Analysis of recent research works and publications. To understand the senses, incorporated in these artworks, it is crucial to keep in mind the facts of Gnilitsky's biography, to comprehend artist's beliefs, to consider nuances of the time he lived and worked in. It would seem obvious to use same old methods: in a study, as throughout and detailed as possible, to analyze historical era, biographical facts, scan publications, interviews with painter's relatives and friends - and retrieve quite accurate picture of the artist's work, get formulatable conclusion.

However, unlike the Western art with plenty material to start research with, Ukrainian contem- 


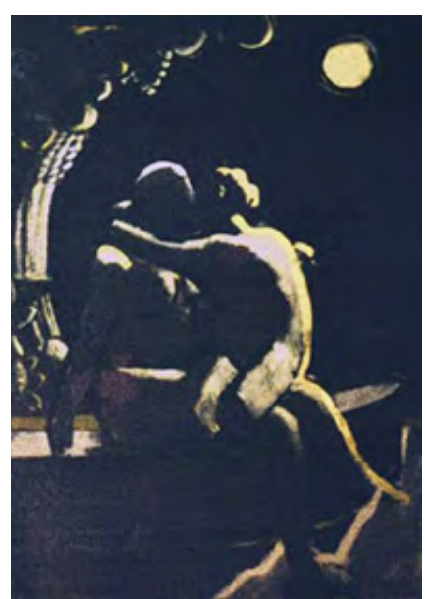

Moonlight Lovers. 1987, oil on canvas

porary art and achievements of its artists still lack sufficient publication coverage. Among the sporadic articles the ones that should be named are authored mainly by Oleksandr Soloviov (facts, used for this research, are derived primarily from Soloviov's works from different years). Other materials used are: interview with Gnilitsky (October 2008, by Alesker Aliev [3]), materials from his solo exhibition catalog Modesty and Lard (October 2008 [13]), materials from the catalog of the group exhibition Olive seed (2010 [26]). Gnilitsky's works were also studied by O. Avramenko [2], V. Burlaka [6], D. Zholdak, A. Lanidkhova [11], V. Levashov [12; 13], A. Lozhkina [14-17], N. Matsenko, O. Petrova [21], N. Prygodych, O. Soloviov [13-17; 25], N. Filonenko.

Analysis of historical and cultural context. Artistic outburst of the late 1980s was preceded by a string of symptomatic, innerly related phenomena of cultural and art life that did not fit into the framework of official Soviet propaganda. They were illegitimate, underground associations that fundamentally opposed petrified canon of Socialist realism. In the second half of the 1980 s, driven by Perestroika, these associations became grounds and stimulus for self-manifestation and hectic activity of young artists who longed for a taste of freedom. The country has been changing, collapse of the USSR inevitably approaching. Along with it, totalitarian art has been gradually losing its status of indisputable dogma, its more and more questionable "urgency" of ideologically "right" themes and characters has been fading. In a country where everyone seemed to dream to even breathe in a new manner, it was inevitable for the "new" art to emerge-the upto-date art, contemporary to global trends. It was the time for young artists to realize that not only authorities may and could build up an art strategy, that such strategy may not be the identical for all artists. It turned out that artists may and should become creators of their strategies themselves.

It was the time of exhibitions of young artists, AllSoviet Union or republican. These exhibitions turned into the centers for dissemination of new movements, art platforms, where self-expression of youth, avoiding vigilant censorship, became more and more confident. Even the slightest ideological loosening, such as isolated permissions to exhibit "non-standard" artworks, was interpreted by the new generation of artists as a radical change and an appeal for yet more daring and sweeping actions, for further movement in certain direction, that became more and more exciting and serious. The capitalKyiv-took the lead in this movement: all but a few solitary "provincial rebels" (like the artists from Odesa and Kharkiv, whose names are now engraved in the history of Ukrainian contemporary art) were graduates of Kyiv Art Institute. It was a paradoxical way to pass on the baton: the teachers of nowstars where acclaimed masters of Soviet painting (V. Zaretsky, O. Lopukhov, V. Puzyrkov, V. Chekaniuk, T. Yablonska), who occupy their rightful place in the museum collections and in textbooks on Ukrainian fine art of the $20^{\text {th }}$ century.

The feature of All-Ukrainian exhibition Youth of the Country, held in Kyiv in March 1987, was its competent design by the group of Kharkiv-based architects (V. Bondarenko, O. Kudinova, M. Gluschenko). However, usual fear of any changes, and above all-fear of their own overly daring idea, caused paradoxical vicinity of the "old" and "new" art expositions within one exposition space. 


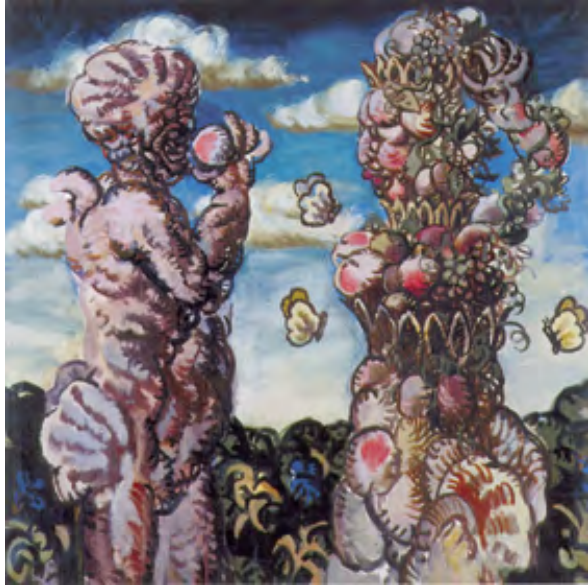

Discussion on the Mystery. 1988, oil on canvas

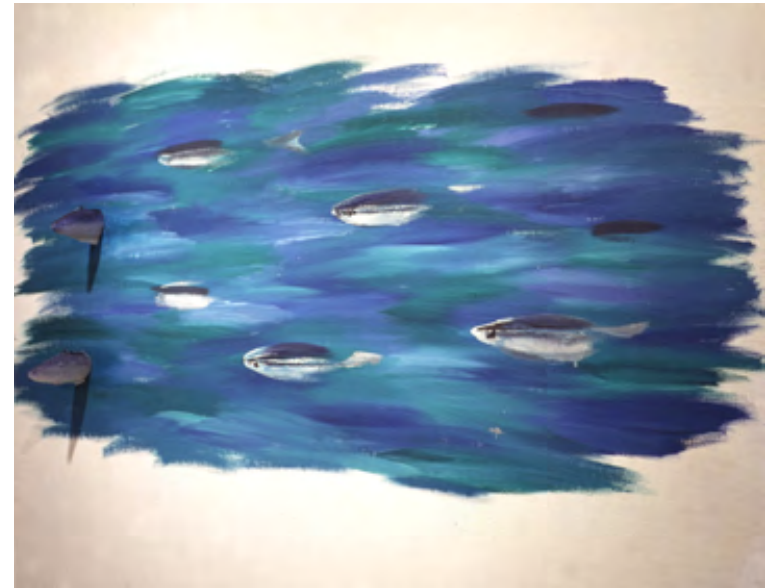

The Call of Laodicea. 1989, oil on canvas
This exhibition proved to be drastically "dissimilar" in quality of presented paintings; still, at least, it emphasizes obvious changes. Due to obsequious loyalty of organizers-administrators, the whole exhibition got a mocking implication: monumental works of socialist realists were elevated, almost up to the ceiling, meanwhile at the eye level a viewer could discover new, then-unknown names: M. Heyko, O. Golosiy, O. Diachenko, P. Kerestei, S. Panich, O. Roytburd, V. Ryabchenko, A. Savadov. O. Sukholit, O. Tistol etc., O. Gnilitsky among them. Kyiv public, as well as the Moscow onein the heart of "Soviet Homeland" - was highly interested in such artistic landing of young artists and sculptors who presented their creations, new and unusual both in concept and in performance. Long queues snaked to the Kyiv House of Artists, its halls hosted concerts by popular rock bands. Shortly after, that very spring, another young artists' exhibition took place at the Kyiv Polytechnic Institute: Kyiv-Tallinn, still remembered in the art circles as one of the outstanding art events of the late 1980s. Among the exhibition participants were G. Vysheslavsky, O. Zhyvotkov, M. Skugareva, A. Stepanenko, and O. Tistol.

Official Kyiv, alas, gave no reaction. Publications coverage and professional criticism, received by this exhibition, were not sufficient. In 1987 no- body could predict, for how long Perestroika would last, therefore authorities chose the waiting strategy, preferring to overlook the radical changes, marked with mentioned exhibitions. Nevertheless, Kyiv proved to have contemporary art, worth and suitable for serious attention, exhibiting and discussing. The participants of these first projects nowadays constitute a central, initiative-action core in the art of contemporary Ukraine.

“New Wave". Influenced by civil transformations, the new generation of artists with distinctive features, style and stances emerged in Ukraine by the early 1990. It was titled eloquently-the "New Wave". It should be noted, that in shaping this phenomenon, in describing it and revealing its conceptual core very important role was played by the art researchers and their texts. Among Ukrainian critics highly active and influential was O. Soloviov, not least because his personal friendship with his peers from the "New Wave" favored his studies of topical issues of Kyiv art scene. G. Vysheslavky, one of the active members of the movement, has recently conducted a study [7] of how artistic and conceptual grounds of the "New Wave" had formed.

On the edge of the 1990s, the work Transavantgarde International by acclaimed Italian critic Achille Bonito Oliva [10] was highly popular among artists. Bonito Oliva coined the term "transavantgarde", de- 
noting one of the most productive and interesting movements in Italian and generally in European art of the late 1970s and early 1980s. This largescale, expressive, postmodern painting style of various configurations was practiced by such masters as Sandro Chia, Francesco Clemente, Enzo Cucchi and others. Young generation of Ukrainian artists, despite not being directly, visually acquainted with the works of Italian colleagues, still pursued transavantguarde fondly. Trying to make for the lost time, they sought knowledge about Italian transavantguarde firmly and stubbornly, from any sources, be it articles' abstracts from the foreign journals (worth their weight in gold at the time!) or even oral retelling. That is how, in conclusion-"heard something", invented, carefully analyzed, thought for themselves, re-worked some ideas-emerged an art product of their own. As Oleksandr Roytburd, another "new waver", testifies in one interview, "We had read something and invented our own Ukrainian transavantguarde, totally different from the Italian one. Similar to how it happened with the Russian Futurism" [9, p. 18]. Bonito Oliva thus became a cult figure in these circles. His influence on the "New Wave" artists was so profound, that even his name became some kind of a password, though he was completely unaware of that. In the mid-1990s, when Marta Kuzma was a curator in Kyiv, Bonito Oliva was invited to give two lectures at the Soros Center for Contemporary Art. Upon his arrival, Oliva visited a number of art studios. When he saw old Gnilitsky's works, "He exclaimed with the tears of joy on his eyes, 'Pittore! Pittore!' approached the artist and gave him a hug. Fine art! He saw in him the character from a book of his own, a prototype he objectively could not have known when he wrote it. That was a belated, yet eloquent recognition" [13, p. 7].

Common feature of the "New Wave" painting style is, first of all, its natural interest in Italian transavantgardia, hence-large scale, expressiveness, disturbing myth-like themes and accented, spontaneous psychedelic traits. Another defining feature was the quality of painting technique. It was in no way the "classical academic painting", nor in themes, nor in techniques. From the "canonical painting" all what was left was the canvas. Even paint was not always professional oils. The essence of their experiments was not in technical side of painting, but in achieving emotional expressiveness. "A work could be pronounced completed at any stage, without the need to draw some tiny details up to some blazing perfection. What was valued above all were spontaneous, wide brush strokes, impulsivity, vitality, even selection of a fluid household paint over the professional viscous ones" [15, p. 33].

The "New Wave" generation transformed into accomplished phenomenon rather quickly. After the striking achievements of the late-1980s harshly came the maturity. Years 1990-1992, according to researchers, was the era of the "New Wave" triumph.

A path towards formation of Gnilitsky's creative personality. Oleksander Gnilitsky was born in 1961 in Kharkiv; in 1980 he graduated from the Kharkiv State Art School from the Department of Theatre and Decoration Painting, majoring in "scenography art". A pupil of good teachers, he gained the skills of stage painter, becoming a man, prompt at creating a sham reality. Afterwards that manifested itself in his creative ideas and was the reason, why Gnilitsky's works are so striking, comparing to the others from the "New Wave". During his lifespan, Gnilitsky turned to almost every existing genre, technique and kind of art, available in contemporary visual practices: he produced videos, created installations, kinetic sculptures, anamorphoses, zoetropes, paradox design opuses, DJ performances [1, p. 68-69]. Due to his changeable, irrational modus of existence Gnilitsky was the least predictable artist in Ukrainian art process, provoking vagueness, blurriness of characteristics to describe his art. This defined the strategy of his path, close to the Neo-Dadaism, where carnival and toylike absurd reality conceals a deeper tragedy, hence the need for constant mimicry, sliding away, transformation. During his transavantguarde period, Gnilitsky's style went through several modifica- 


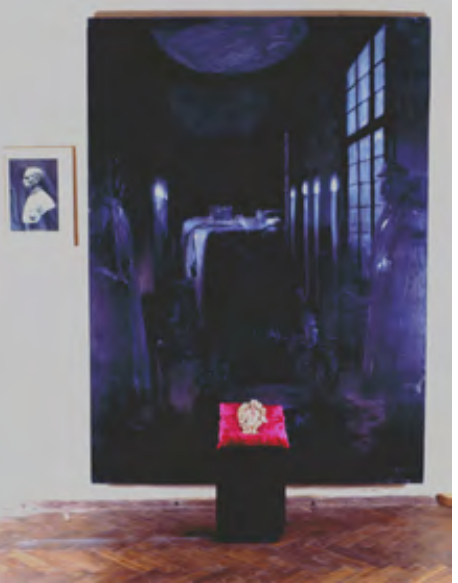

General Gallieni. 1992,

installation

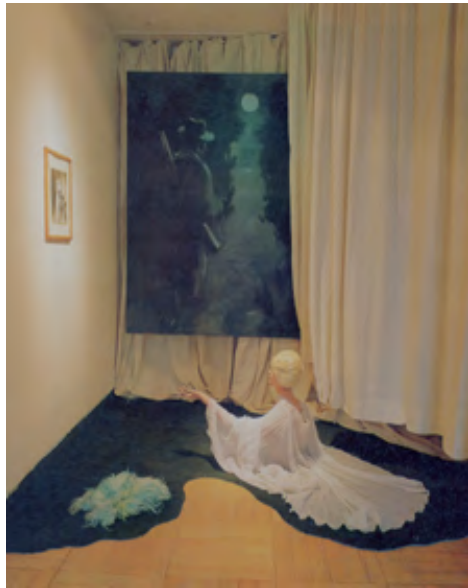

Key and the Moon Hunter. 1992,

installation

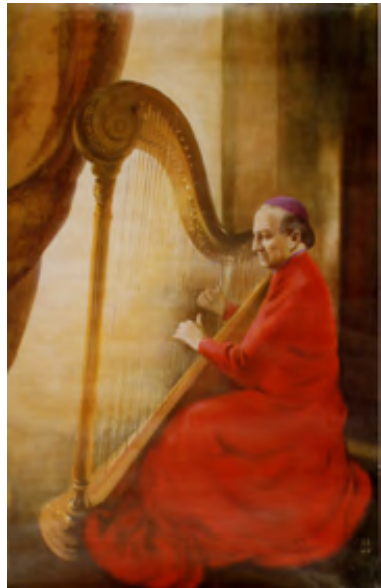

Untitled, from the Clericalos series. 1995, oil on canvas tions: "curly style", greenish "wave painting", black and white grisaille, "childish discourse"..

For instance, one of Gnilitsky's trends was some sort of "dummy" sculptures, creating Neo-Dada kinetic objects: The Mechanical Skeleton Blowing Bubbles, Tomb of Tamagotchi, Old Beggar Lady, and Miner on Strike. The sculptural mechanics of Show Me Yours installation reveals the idea of infantile wishes as the yet unformed sensation, the conflict between the "dead" technology and "animated" flesh.

During the 1990s Gnilitsky created numerous such objects, Anamorphoses among them. According to scientific classification, anamorphosis is an optical phenomenon that produces distorted image. In fine art, it is a deformed image of a kind, something like an optical rebus, possible to solve if observed in distorted reflection (conical or cylindrical mirror). Anamorphosis is rooted in Renaissance studies of the rules of perspective.

This genre or, more precisely, art trend became popular (except of the wall paintings of the Italian Renaissance) before World War I (for instance, Nabokov praised it in his memoir and in Invitation to a Beheading). Recently it has been revived in a digital variant in contemporary Europe. Gnilitsky took a more serious approach to creation of his Anamorphoses. "He produced some kind of tubes of mirror plastic, made deformed wall and table paintings that turned out just right in a mirror reflection. He calculated everything without a computer, without any digital help. On paper, writing on his lap, as they say $\langle\ldots>$. It was his 'thing' in the 1990s" [13, p. 10].

In 1984-1990, he studied monumental painting at Kyiv Art Institute, Vilen Chekaliuk being one of his teachers. During his student years, Gnilitsky loses interest in the classical painting and sets his eye on the non-standard (according to Soviet norms) fine art by his older peers from the institute: V. Tsagolov and A. Savadov. He chooses this art as his guiding line.

According to O. Soloviov recollections, "first works, displayed by Gnilitsky, were mainly still lifes. Carefully painted, with strong academic background... Expressionism, delicate combinations, without further revision" [13, p. 6].

For the mentioned 1987 exhibition, he painted Moonlight Lovers that did not resemble any previous painting. It is gentle and moving image: two lovers embracing and kissing. Their silhouettes are generalized, built up in the contrast of light and shadow. The background is absolutely black, lovers' silhouettes are only gently hinted on with warm moonlight contre-jour. It takes time for the viewer, ob- 
serving this romantic pair, to notice the girl's legs: cut below the knees. Chopped off. That was a nonstandard and radical element. Worker and Kolkhoz Woman, painted in the same 1987, has similar stylistics.

That were years of great change in art life, bringing crucial transformations. Gnilitsky with the inconstant, revolutionary stream of the "New Wave" was among the pioneers of this movement, who eventually formed present-day contemporary art space. His style constantly altered. His subsequent works (Discussion on the Mystery, The Call of Laodicea, Ausonia-the Abode of Paradise, Angel, Temptation), labeled a "curly style" by researchers (O. Soloviov, [13, p. 7]), radically differed from the previous ones. The form is painted on the upper layer with small, lacerated brush strokes. An image is never modelled in detail; it never has been an aim for Gnilitsky. The devil is in the hidden allusions or pointed citations.

Aside from the inevitable collapse of the USSR, another background event affected the public: the Chornobyl nuclear reactor disaster; its consequences once again hushed up by the authorities. It was time to think deeply, to absorb and produce an "art product" after careful and hard inner refining. Young artists have chosen the most appropriate strategy: to veil an acute pain with the cynical irony. That radically different approach to art, formulated and adhered to by the "New Wave" artists, remained obscure to a conservative surroundings and served as a cause for condemnation. Therefore, artists' desire to physically demarcate their community, to have a sovereign territory for creative self-realization became one of the motives for organizing a squat.

"Squat" in a general meaning of the word is an abandoned, neglected building, occupied by different kinds of marginals. However, La Rouche squat, well known within the history of Western art, where Fernand Leger, Amadeo Modigliani, Mark Chagall lived and worked, was not simply a refuge for social outcasts. From the beginning of the $20^{\text {th }}$ century, artists practiced collective creative cohabi- tation, like the free Abbey of Thélème that François Rabelais dreamt of. Therefore, for the artists "squat" at the first place means studios. Since all artists of the "New Wave" tended to work largescale, they, naturally, needed spacious workshops that would reinforce hope for success and proper appreciation of the "new art". The ideal space for that were old, uninhabited high ceiling communal apartments.

The first settlement of a kind was founded by the "New Wave" artists in Kyiv in the late 1989 and existed till summer of 1990 at the Lenin street (currently Bohdan Khmelnitsky street). According to the researchers, it was the most prolific period for the whole generation. Among the squatters were O. Gnilitsky, O. Golosiy, D. Kavsan, Yu. Solomko, O. Tistol, V. Trubina, V. Tsagolov and others. Odesa-based Oleksandr Roytburd visited on any occasion. He recollects about this time, "Everything emerged very fast. Golosiy could do two painting for a night, 2 × $3 \mathrm{~m}$ each. I envied him dearly, as I needed the whole day to complete one such painting. It is unclear to me now, where did we get the energy that days; it seems to me now that the thing was not in the age, but in the very air of those years: the drive was there that forced us to work, inspired desire for expansion" [22]. The works, later dubbed by Oleksandr Soloviov as the "wave painting" [13, p. 8], are dated back to the period of the Lenin street squat. These pieces are most often in emerald-green (like $A$ Wave and a Boy) or blue spectrum (Fishes) that signal Gnilitsky's transition from the "whole palette" painting to color minimalism.

Living and working close aside caused, to a significant margin, likeness of aesthetical preferences. For instance, during the Lenin squat period Gnilitsky, just like his closest friend O. Golosiy, produced black-and-white works-grisailles, where the surface of a canvas is only partially covered with layer of paint. That period of both artists' careers was later labeled a "childish discourse" [22]. It would be hard to invent any other definition for the works, performed with uncertain hand, almost child's one, exaggeratedly sloppy, with paradoxical, a bit ter- 


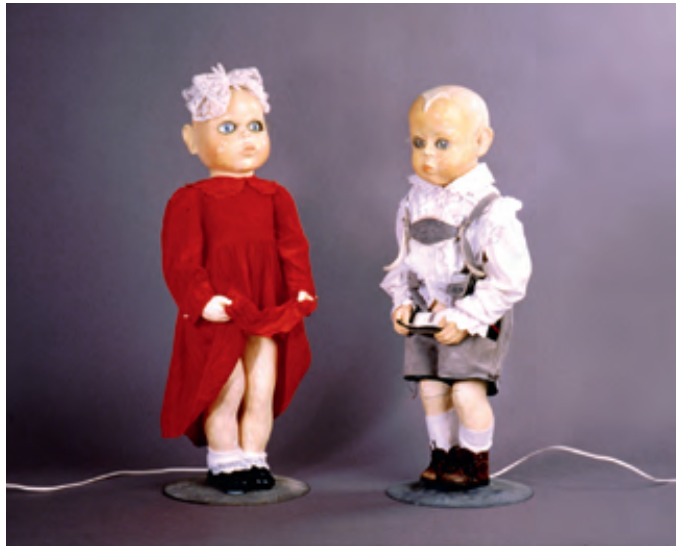

Show Me Yours. 1998, mixed media/installation

rifying themes. These are such Gnilitsky's works as pronouncedly erotic Napoleon and Marysia, Lisa Cries (depicting either a girl or some big-eyed monster of deformed proportions), Daddy, a Helmet Is Tight, Chu, Little Zephyre, Chicken Soul, Three Musketeers etc.

The landmark event of this period was participation of Kyiv artists in a grand Moscow Babylon exhibition, organized by a novice gallerist Marat Guelman. The title was quite conceptual, as the exhibition united artists of different nationalities, symbolizing the reaction on the collapse of the Soviet empire. The event did not receive unambiguous positive appraisal. Critics were excited, yet reaction of the peer artists was catious, even chilly. O. Roytburd considers it a veiled fear of competition, "As for me, personally, Babylon was a successful project. From the present-day point of view all of the presented pieces are if not masterpieces, than definite hits" [22].

What should be noted is that by then Moscowbased conceptual artists, keeping up with the global trends, have already lost interest in pictorial surface and two-dimensionality-they went into volume and space; meanwhile Ukrainian exposition was made entirely of flat object that is, paintings.

In conclusion, it was a definitely positive change for Ukrainian artists: exhibition caused standpoint and aesthetic transformations within the "New Wave"

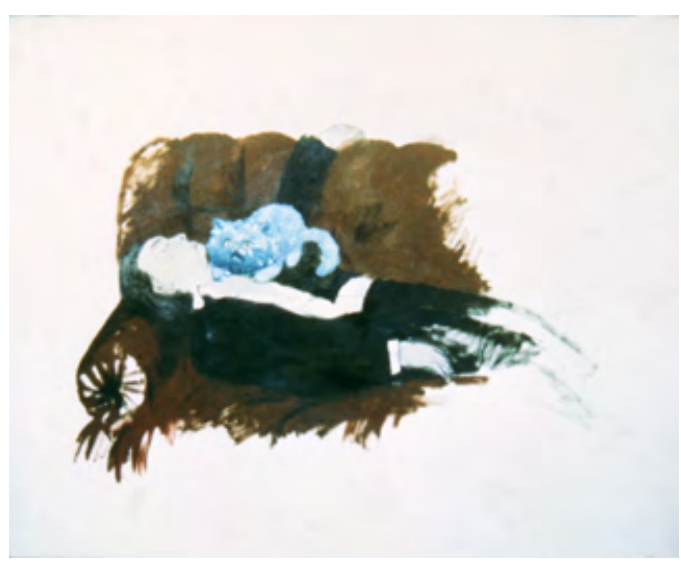

To Feed a Kitty. 1990, mixed media of canvas

artists, leading to a gradual shift from the painting practice. It became obvious that "neobaroque" becomes a thing of the past; that painting, not only traditional one, but overall, is no more topical, losing its supreme position. New artistic language was about to be found.

In fact, Gnilitsky took a lead in these experiments, being one of the first Ukrainian artists to create and exhibit installations. He shifted to the new trends quite easily, later becoming totally captured with digital projects.

"Paris Commune". In the summer of 1990, the artists were forced out of the Lenin street squat. However, they quickly found a new safe heaven: on the Mykhailivska street, then-named after Paris Commune. Thus the new squat was without second thoughts labeled "Paris Commune", or, shorter, "Parcom". This, until recently, quite common "apartment block 18-A" in the central Kyiv became a true core of contemporary culture and art for the whole city, a source of news and events for young artists.

During the initial period, the life in a squat took its usual course: artists kept up with the previously established rhythm, creating yet another works without any second thoughts. Still, gradually another function of the squat started to emerge. Namely, it was a good place for communication for the progressive youth; although that affected and slowed down productivity, it became more important for the sub- 
sequent artists' development. "Not only painters, but all avant-garde youth of the city gathered there: musicians, poets, first IT professionals, dandies, first contemporary collectors, gallerists; Western curators started visiting, interested in the newest trends of Post-Soviet art" [15, p. 35].

The district of Mykhailivska street itself (thenParis Commune st.), constituted of the radial streets around the Maidan (an Independence square) was a bohemian quarter for the whole contemporary Kyiv, as the Latin Quarter was for Paris. I. Yusupov, P. Kerestei, A. Savadov, G. Senchenko, I. Chichkan had their studios there. "Paris Commune" hosted L. Vartivanov, O. Gnilitsky, O. Golosiy, D. Kavsan, O. Klymenko, Yu. Solomko, V. Trubina, V. Tsagolov and others, who lived and worked there. Odesa-based S. Anufriev, one of the leaders of the Inspection Medical Hermeneutics Moscow art group famous for his charisma, also visited the squat often. Therefore, this small quarter had an unusually high concentration of creative youth. They paid each other visits, exchanged ideas, discussed their works and, off course, had fun. For the most artists of this generation it was a turning point in their personal development.

At the time, the most popular authors among the progressive youth were William Burrhouse, Carlos Castaneda, Timothy Leary, Henry Miller and other creators of the "new morale". Publications by Timothy Leary, a writer and psychologist, who researched the influence of psychedelic substances on a human brain, were extremely popular and had a great impact on the Western pop-culture of the late 1960s. Kyiv-based artists welcomed his ideas in the early 1990s. Young painters began to "go over the limits" of consciousness by all accessible means. Be it the newest musical achievements as a natural accompaniment to equally intense discoveries in the field of contemporary fiction, or, by chance, pharmacological, narcotic experiments with their own unconsciousness-they were something nor rare, nor extraordinary. Taking hallucinogenic substances "to go over the edge" has been treated not as a trite "moral decline", but was a natural sign of belonging to the newest worldview and having corresponding philosophical ideas. The "Parcom" air was totally free of any stereotypes. There were no taboos. Along with the creative revolution, the narcotic and sexual were happening there as well. "New Wave" art reached its high point, maturity, meaning inevitable decline.

As it has been mentioned above, shift from the twodimensional and flat painting was revolutionary for the "New Wave". Gnilitsky was one of the pioneers of this "outbreak into space".

During the "Paris Commune" period, the namesake Artists of the Paris Commune exhibition was organized in the gallery of the Union of Artists of Ukraine in 1991. This event revealed Gnilitsky as a talented installation artist due to his piece Key and the Moon Hunter. The installation is made of four objects: woman half-figure (dummy), standing on a floor, as if emerging from the depth of dark evening waters; animal skin, probably imitating a dog near a woman; large painting on a wall, depicting an armed hunter, who is moving away, with a night river on the background; and finally - a tiny reproduction of a Louis-Léopold Boilly piece accompanied with the poem (currently lost), being, according to the plan, the sense of all performance. The painting is of black and emerald green-grisaille-the moonlight contre-jour revealing the hunter's silhouette. The floor is painted in black that apparently imitates the course of the river from the painting. The woman dummy is turned over to the hunter, passing a big key to him. The underlying theme is equally definite and broad in all possible senses.

Another piece from this exhibition that proved Gnilitsky to be a skilled installation artist was the Squirrel. On a blank white, almost untouched canvas from the very center of it comes the plush squirrel namely, its upper part. The lower partsquirrel's feet and tail-artist painted by hand, as well as the shadow that should be cast from the threedimensional squirrel. Compositionally squirrel is positioned in the center, diagonally to the canvas. Therefore, on the white surface of a canvas it looks 


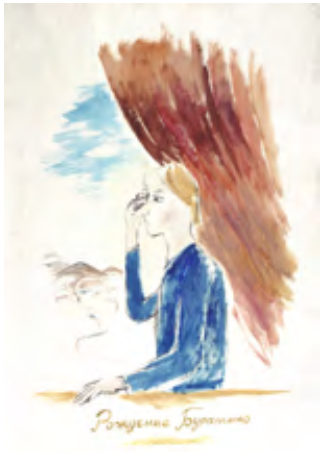

The Birth of Buratino. 1991,

oil on canvas

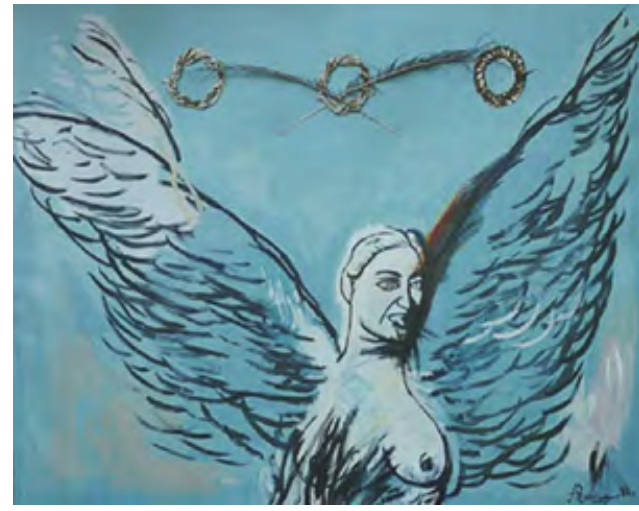

The Call of Laodicea. 1989,

oil on canvas

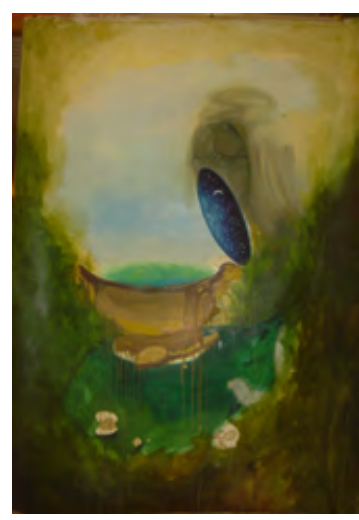

Cosmic Soup. 1991,

oil on canvas like a pin, falling slantwise from the top right corner. The work is intensely laconic and graphic. Indeed, any of Gnilitsky's peers and colleagues could get the underlying message: allusion to the alcoholism in its last stage, delirium tremens (that is colloquially called "squirrel" in Ukrainian); this game of meanings on the edge of acceptable formed the concept core of this piece.

In the very same 1991, at the Gallery 1.0 (Moscow) a joint exhibition of Gnilitsky and S. Anufriev-As planned-took place. Gnilitsky was represented mainly with his black-and-white artworks from the "childish discourse": Lisa Cries, Napoleon and Marysia, Daddy, the Helmet is Tight etc. They proved it was a time for inevitable inner transformation, searching for the true self: Gnilitsky leaves less space for paintings in his work, engaging with the new aesthetics instead-with the aesthetics of so-called "cutism", a deliberately simplified art with the reduced intellectual component and substituted it with naïve, "cute". Composition becomes more discrete, an image loses its previous neobaroque traits, mythological ampleness, and they are no more overly rich in colors and textures. The artists "breaks up" with painting, however, as time will show, not for good. That was another landmark, another experiment. Being a true inventor, a creative person with many faces, Gnilitsky repeatedly astonished the viewer with unpredictability and de- lusion of his works.

The trend for simplification captured the whole "New Wave" generation. Crisis of the postmodernism, becoming its end, seized the world art back in the 1980s. Young Ukrainian artists that caught the last breath of postmodernism, could not maintain life in this "dead art" for long. It was clear that the recent contribution of contemporary Ukrainian artist to the global culture, seemingly so noticeable, is now out-of-date: Neobaroque steps aside, leaving space for the new forms of artistic expression.

1992 started with a dead Calm-group exhibition in an exhibition hall of the Union of Artists of Ukraine. According to the participants' concept, it should prove the degeneration of the Neobaroque and shift from burlesque transavantguarde to austerity and minimalism. All exhibited artists comprehended on a conscious level that it was an ending of Ukrainian transavantguarde. Ironic underlying message of the exhibition was revealed in its subtitle: Dead art [25, p. 148-153]. Afterwards it would be clear that this was a landmark exhibition, signifying the "New Wave" transition to the final stage of its development.

Artists of the "Paris Commune" cohabitated for a couple more years, but by that time no one actually declared any ideological unity or common ideas, affiliation with more or less certain common movement of trend. 
Back at the Calm exhibition Gnilitsky presented his Funeral of General Gallieni that later caused scandal in Edinburgh. Gnilitsky teared off the portrait of some mythical general from the early $20^{\text {th }}$-century journal. As in the hunter installation, the artist builds the composition on the similar principles: tiny portrait of the general on the wall and huge painting by Gnilitsky, depicting funeral procession. In a dim room a coffin is surrounded by a few candles and two armed guards of honor. This is the funeral of General Gallieni. Painting is performed with cobalt and whitewash. The portrait of the general is also in white and blue spectrum. The contrast spot in the foreground are general's insignia on a small pedestal, being hyperbolic plastic moulding woman's genitals, that artist made for himself and ornated with the rhinestones. The insignia rests on a red velvet pillow, as it is supposed to be. This decoration was afterwards simply stolen, as if proving the value of Gnilitsky's artistic innovation.

International experience. Dialogue with Kyiv. Leaving transavantguarde behind, none of the artists had any clue, what turbulent events were ahead of them. The "New Wave" art story experienced an unexpected turn, initiated by the Western curators, who organized a number of exhibitions.

In the early 1990s, after the fall of the "Iron Curtain", not only Post-Soviet people were amazed with all the new; foreigners were interested in Ukrainian culture as well. Soviet art was in trend among the foreign collectors at the time. Foreign collectors also frequently visited the Post-Soviet grounds. They held some kind of competition in discovering new talents. They arrived, inspected artists' studios, acquired paintings, and formed a general notion about art situation and offered curatorial projects later on. Such "reconnaissance" on the Ukrainian grounds marked initial activities of George Soros, US millionaire of the Western European descent, whose humanitarian and social projects would later play a significant role in formation of local art situation. Due to intervention of Western curators into the course of de- velopment of contemporary Ukrainian art happened the burst of interest in video art and curatorial process itself by Ukrainian artists. It was in the 1990s, when now-renowned Kyiv curator Natalia Filonenko (Gnilitsky's wife at the time) graduated in curatorial practice in United States. This beneficial exchange of experience nourished hope for further development and long-awaited international recognition for contemporary Ukrainian art, so it could gain rightful acclaim at the global art scene.

The first curator to organize an exhibition of Ukrainian fine art abroad was German Christoph Wiedemann. He arrived to Kyiv in the spring of 1992 and happened to visit the Calm exhibition; under the strong impression from the exhibit, he subsequently visited the "Paris Commune". Visited, evaluated, considered and made an offer to organize the "New Wave" exhibition in Munich, Bavaria.

Wiedemann carefully chose the works for the exhibition by himself. As a result, Kyivites O. Gnilitsky, O. Golosiy, O. Druganov (as a press photographer), P. Kerestei, A. Savadov, G. Senchenko and Odesa-based D. Dulfan and O. Roytburd were invited to Munich. The Munich project was generally titled Dialogue with Kyiv.

Two exhibitions were planned within the project. First-Dialogue with Kyiv'1-was organized right after the arrival, in September, at the main hall of Franz von Stuck villa, now hosting an art museum. All of the exhibited works were the ones that Christoph Wiedemann had chosen back in Kyiv. Second-PostAnaestesia-should have presented the pieces, produced by the artists during their Munich residency.

Living abroad for four months became an important stage for the painters, most of whom newer had never crossed the state border before. They had a chance to see with their own eyes the German cultural heritage, to witness contemporary art in the making. They spent some time in exaltation, visiting cultural sites: Old and New Pinakotheks, Lenbachhaus, various Munich galler- 


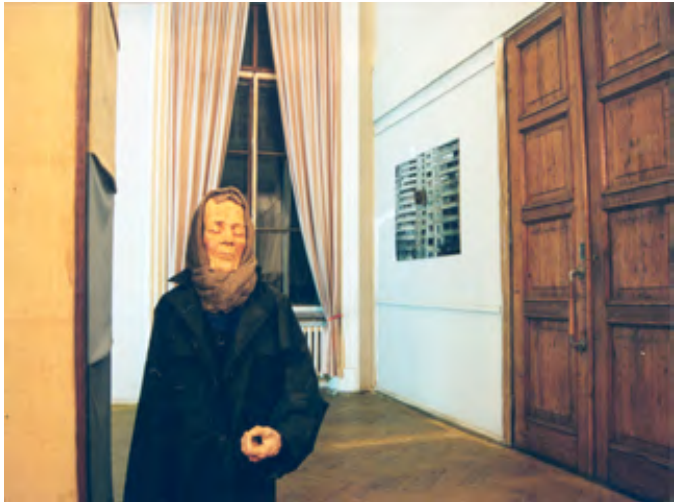

Old Beggar Lady. 1999, kinetic sculpture

ies. Until something really life-changing (like the Cleopatra success) happened: documenta IX that very year in Kassel. Taking place every five years, being one of the events of global cultural importance, documenta defines direction of art development for the years to come. That was the moment of culture shock for Ukrainian artists, as they saw very little paintings on display; predominantly it were spatial installations, photos and new media. Documenta's enormous authority and understanding of the huge gap between the exhibited art and their own, as well as an urge to keep up with the topical trends, forced artists to rethink and double their efforts in creating works for the future exhibition.

PostAnaestesia initially was exhibited from December 1992 until January 1993 in Munich city gallery at Lothringer strasse, afterwards - at the Grassimuseum in Leipzig. It showed, how strikingly the artists spurted during their short of four months in Europe. Each of them produced a newformat works, nothing like their previous painting practices.

In Munich Gnilitsky started doing completely new graphics and painted extremely large-scale grisailles with vast areas of untouched canvas. For instance, the Franskenstein Portrait (recently displayed at the Independent exhibition in the National Cultural-Art and Museum Complex "Mystetskyi Arsenal" in Kyiv, August 2017) was pro-

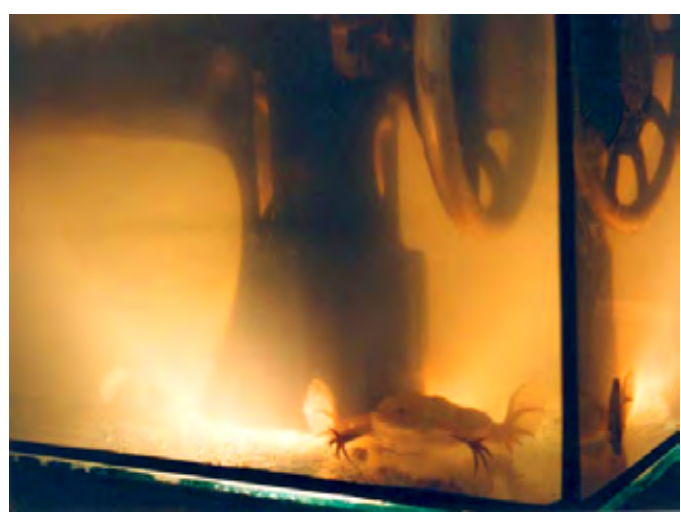

Untitled. 1997, mixed media

duced during that Munich residency. The Frankenstein image, made up by the artist, depicts a man with abnormally high forehead, massive brow ridge and deliberately silly facial expression. Perhaps, that is how, according to the artist's idea, a mix of two characters-the scientist's and the monster he created-should look like in collective consciousness. It is quite characteristic to Gnilitsky's style that despite the massive forehead, jaw, and eyebrows, the painting does not leave a hard feeling; thanks to blank areas, it is full of air and ease.

Another big international exhibition took place in the summer of 1993 in Edinburgh, Scotland. Titled Angels over Ukraine, it was held at the local Apostolic Church. That was the venue where Gnilitsky presented his General Gallieni, insignia from which were so highly estimated by the thieves. In October 1993 another international projectSteppes of Europe-was initiated, its curator being Jerzy Onuch, a Pole of Ukrainian descent. These first international exhibitions, mentioned almost randomly, were of high importance mostly because they caused an inevitable change in artistic orientation. Painters were gradually shifting to the media art.

Gnilitsky's art of the mid-1990s is marked with almost complete absence of painting and progressing passion for video art. By March 1992 he produces his first video Sleeping Beauty in a Glass Coffin, that is considered to be perhaps the first art video 
in the history of new Ukrainian art, and Gnilitsky, accordingly, to be a founder of video art in Ukraine. Gnilitsky engaged his then-wife Natalia Filonenko in his poem-performance: she played the beauty in the coffin. Gnilitsky made a coffin by himself and wrote the text for the poem. Video footage $(25 \mathrm{~min})$ perfectly matched the text, recited by Gnilitsky. Audio is deliberately distorted, drawling, resembling popular at the time amateur dubbing of foreign films. The beauty in the coffin masturbates. Happening in the dark, under the moonlight, it left impression of some kind of decadence extravaganza.

Another video by Gnilitsky-Crooked Mirrors - Live Paintings (1993) - clearly illustrates the theme of sexual emancipation and "rejecting filters of shame" [13, p. 10]. In this work the artist is both an author and a hero of the video, engaging his wife and close friend Maxym Mamsikov into the production. After buying props from a "house of mirrors" for ridiculously small sum of money, the artist places them in his studio to film a video-reflection of the explicit sexual content.

The optical system built by the artist provoked a surprisingly strong flow of surrealistic Dalí-like images. "Forms diffuse, separate from one another, male and female genitals increase grotesquely. Legs clad in shoes dancing to the Beatles $<\ldots .>$ Harsh, radical and extremely beautiful piece" [13, p. 10]. This work was on display in the National Art Museum of Ukraine during Gnilitsky's posthumous solo exhibition Cadavre Exquis (September-October 2011), dedicated to the painter's $50^{\text {th }}$ birth anniversary. In 1994, it has been on view during the Soros exhibition Alchemic Surrender on board of Slavutych military vessel.

As it has been mentioned before, painting in Gnilitsky's work for a time became almost nonexistent. In June 1994, history of the "Paris Commune" squat also comes to an end. Long-awaited reconstruction of abandoned building finally started and artists were forced to find yet another shelter. However, by that time it became absolutely obvious that to move on under the banners of the "New Wave" means going nowhere. The fact that they still worked under the same roof was caused simply with neighboring studios: they no longer shared common aesthetical grounds. Therefore, after unavoidable "Parcom" closing, it was not substituted with anything alike. Since that moment, each artist would experiment for himself, searching for his own niche in Ukrainian art. Still, along with the "Parcom", such original and outstanding phenomenon as the "New Wave" remains in art history for good. The "New Wave", that in time became legendary, marked the beginning of new era-present-day contemporary art.

A telling illustration of the state of artistic confusion that was in the "Parcom's" air at the end of its existence would be one of the random texts (1994) by Gnilitsky, "Children of the 'Paris Commune', your sperm is poisoned with unbelief, your sperm is sterile. Children of the 'Paris Commune', you have not experienced a joy of flesh, as your spirit rushes towards emptiness. You are upright Asians, who incarnated into the fashionable jest of the Europeans, who embodied the gallant flirt of the Enlightenment into the bloody delivery of the Revolution, who had held a postmature creature from their womb in their hands and who lived through its stinky decay, who lived through the rotting stench that irritates the nostrils of the brain. Where and how should they move, if their feet are stuck in the rotting body of a beautiful idea? The sun of Capitalism, dry up the corpse of your childthe Great Revolution. Corridors of time, looking like sausages of the stomach, pumping over the shit of yesterday's feast. Time, squeeze a sweet faeces out of yourself onto the beds of new ideas in the paradise of flowers and dancing Krishna devotees" [16, p. 49].

Munich, Institution of Unstable Thoughts. Searching for new ideas, new forms of expression, Gnilitsky creates a large number of spatial art objects. For instance, for the Alchemic Surrender exhibition (July 1994), organized by the Soros Center for Contemporary Art and curated by Marta Kuzma, Gnilitsky presented a kinetic sculpture, 


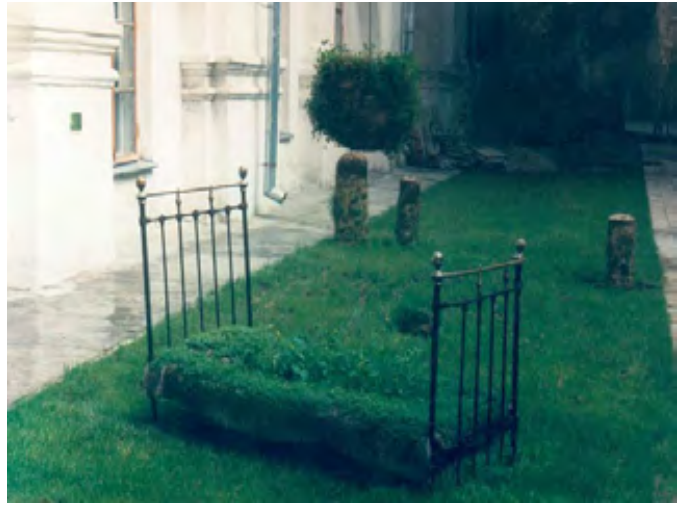

From the Growing Art series. 1998, mixed media

turning rescue vessel into a wash basin, producing bubbles; as well and Telephone the President object-a telephone box that presumably granted an improvised call to the "guardian to the Constitution".

The exhibition was held in Sevastopol, on board of Hetman Sagaidachnyi-the flagship of the Black Sea Fleet, that has been a cause of disagreement between Russia and Ukraine even back then. However, for Gnilitsky personally 1994 was marked with an event, no less significant: his first solo exhibition in Munich-Dairy Maid.

Despite not playing a leading role in the artist's work, painting was still practiced by Gnilitsky as an element of his installations. That is expressively illustrated with the Clericalos series (1995), depicting either a cardinal seated beside a red piano, or a cardinal with the lyre, or a pregnant cardinal; the eggs, rolling around the hall, supplement the whole series.

His search for original artistic language led to founding a non-typical collaboration-Institution of Unstable Thoughts, initiated by Gnilitsky and his second wife Lesja Zajac, animation artist from Munich. Since that moment, Gnilistky would always cite "Kyiv-Munich" as a city of his life and work. It was in Munich where did he get his own spacious studio-the thing he could not even dare to dream about in Ukraine. Still, despite working in Munich, Gnilitsky will be invariably

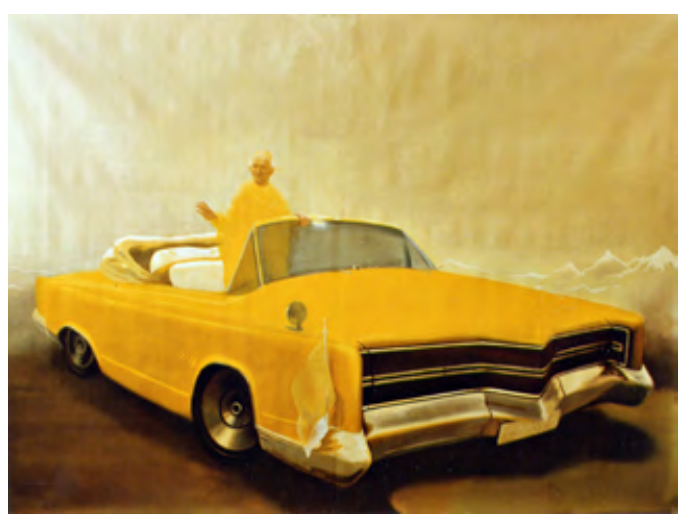

Pope Lama. 1994, oil on canvas

present in Ukraine, participating in exhibitions. "The thing I searched for in Munich was peace. Love and peace. Such a joy: a studio in the city center. Like a green paradise. That is what when it comes to me. Talking about the context-it is Ukraine. I never separated myself from it. I am a citizen of Ukraine, and I do not need any other citizenship. I want to vote, to be present in Ukraine. I love it and it is interesting to me. Here, in $\mathrm{Mu}$ nich, claustrophobia overtakes me-I want it back to Ukraine" [5, p. 68].

After moving to Munich and founding an Institution of Unstable Thoughts, the new era starts in Gnilitsky's career. Since then he collaborated with Lesja Zajac. The collaboration proved to be extremely talented and productive: they created installations, interactive pieces, VJing, kinetics-each of the creative duo was equally tireless in experimenting. "We viewed aesthetics from the common grounds. Besides that, we have very different professional background, skills. I am capable of constructing something by hand. Lesja came out of the film industry. Film editing, sound, video... That is she who fosters love to animation in me" [5, p. 68]. "I am fascinated with the art genres on the verge of established ones. Therefore, our media projects often are hybrids in technical realization and solutions. It is direct opposite to the aims of painting, formulated a millennium ago. Fine art is a square or a rect- 
angle, within which one battles eternity, reality or a container itself, it does not matter what you battle actually" [3, p. 68].

According to this, one could reach a conclusion, that Institution of Unstable Thoughts considered an act of true art to be not necessarily a completed painting-it would rather be a synthesis of fine art, video, mechanics, and sculptural forms, competently placed into the environment, space, situation, and time by the authors. Projects, produced by the Institution (such as Visual Vinyl, Room, Mediacomfort) leave an impression of ambivalent reality. Such balancing between the real and synthesized worlds is so intriguing that it is impossible not to admire the genius of the artist.

Conclusions. Gnilitsky's art should be studied in a close connection to the context of history and everyday life of the era: its situation, time, social and creative environment. Early stage of Gnilitsky's formation as an artist happened during the turbulent times in the history of our country. It was the time, when established painting canon, inscribed by the totalitarian regime, turned out to be archaic and was questioned and subsequently demolished by the new generation of artists. Revolutionary worldview of the contemporary art youth, despite lacking support from viewers and teachers, would later produce powerful "New Art" that will capture viewers' attention for years and result in such phenomenon, as the presentday contemporary Ukrainian art.

Gnilitsky's art should be studied within this very context. Art circles he circulated in played crucial role in formation of his personality. It is indicative that during his career Gnilitsky had never been a loner, almost constantly participating in different art groups and artist collectives. First it were squats and cohabitation with fellow artists, his friends namely, S. Anufriev, O. Golosiy, M. Mamsikov, N. Filonenko, etc. Afterwards his experiments resonated with the tender soul of another fellow artist Lesja Zajac, collaboration with whom Gnilitsky acknowledged as the most harmonious [5, p. 68]. Even when it came to exhibi- tions, Gnilitsky preferred group ones over personal, "It is boring to go on with the same theme, do the same over and over again, just to do a benefit performance afterwards. Group exhibitions are much more fun to participate in" [3, p. 68]. Therefore, Gnilitsky made his exhibition not for his personal promotion or sales, but for the viewer, to engage him "in a dialogue, into reaction" [5, p. 68]. "For me it was important to display paintings, not just sell them. To sell is good, it should be that way; paintings should be eventually sold. Unfortunately, they disappear after that for years, if not for good. First of all, I am interested in people who would visit the exhibition and would react in some way. Just for me, for my own sake-I may as well grow a garden or build a stool" [5, p. 68].

The period of Gnilitsky's career, examined in this article, could be classified, according to V. Levashov [12], as a "baroque psychedelics" that would eventually evolve into the "painting of the lucid clarity".

In summary, it should be noted that the works of the studied period are distinctive of subjectivism, vast citations, self-deprecating humor, cynical reinterpretation of literary plots, use of grotesque exaggeration, motifs of macabre eroticism. "Painting of the lucid clarity" would come much laterduring the artist's mature period; it could be best illustrated with the aphorism phrase by Gnilitsky, "Painting should just be beautiful-as a blonde girl; still, like that blond, it perpetually torments itself with the problem: to be not only beautiful, but also smart" [8].

Within the material, chosen to illustrate trends' analysis of Ukrainian art of the late 1980s and early 1990s, Gnilitsky's figure seems especially pointful, as if symbolizing key features of art of the time: unexpectedness up to epatage, complexity up to grotesque, incorruptibility up to despair and blasphemy-all of the genuine and heroic self-sacrifice of a master. This is particularly true about the contemporary art, fundamentally self-estimated by its exponents in judgement and opinions.

In conclusion, overall picture of Gnilitsky's life and art, as well as his figure almost perfectly 
fit into the ideal (or rather standard) of "avantguarde", previously artistically and philosophically defined. Philosophical definition was formulated by Herbert Marcuse and Theodore Roszak, $20^{\text {th }}$-century American thinkers, who developed and expanded Marshall McLuhan's textbook prophecy of the new age coming-age of total visual media technologies. Marcuse and Roszak amplified McLuhan's statement with the definition of specific self-perception, and, correspondingly, manifestations of its main subject, that is creator, primarily an artist. It is called "proteus", meanwhile all contemporary perception of the world and respective art is "proteus" as well, since previous canons, established and adjusted, seemed to give their place for good to the real storm, astonishing fireworks of new discoveries, genres, stylistics in all the unexpected com- binations and usage that would later be labeled "modern", afterwards - "avant-guarde", later on"transavantguarde", "postmodern" and who knows what substituted or would substitute it next. Similarity to the conclusions from the previous pages about Gnilitsky's art is obvious.

In my opinion, another analogy is exceptionally evident: it is an illustration from literature, from James Joyce's Ulysses that was like a revelation and later a manifesto for all subsequent avant-guarde. The novel developed the first book about Stephen Dedalus-A Portrait of the Artist as a Young Man. Still, it was one of the first chapters of Ulysses, not A Portrait, to be named "Proteus". The only thing it depicts is Stephen's stream of consciousness at the seashore-at the seashore of the ocean of existence, that only an artist is capable to authentically comprehend and reproduce. 


\section{Мітература}

1. 25 років присутності: Сучасні українські художники (Каталог). Київ, 2016. Т. 1. 360 с.

2. Авраменко О. Не вздумай прощаться // Art Ukraine. Київ, 2009. № 6 (13). С. 104-109.

3. Алиев А. Александр Гнилицкий: кто я, гАе я, куда я еду // Unique. 2008. № 10. С. 68-71.

4. Андреева Е. Ю. Постмодернизм. Искусство второй половины XX - начала XXI века. СанктПетербург: Азбука-кмассика, 2007. 488 с.

5. Баймев О. Bloomsday '08, ідеальний вік: Каталог. Київ, 2008. 84 с.

6. Бурлака В. П. Історія Образу: Мистецтво 2000-х / ФонА піАтримки візуальних АосліАжень. Київ, 2011. С. 32-33.

7. Вишеславський Г. А. «Нова хвиля» у візуальному мистецтві України кінця 1980-х - початку 1990-х (соціокультурний аспект): Автореф. Аис. ... канА. мистецтвознавства: 26.00 .01 / Ін-т проблем сучас. мистецтва НАМ України. Київ, 2014. 18 с.

8. Александр Гнилицкий. URL: http://www.nashizdat.com/blog/magazine/78.html (дата обращения: 15.09.2018).

9. Журавлёва А. Художник Александр РойтбурА // Зеркало недели. 2009. № 45. С. 18-22.

10. Звиняиковская 3. СозАатель трансавангарда // Зеркало недели. 1996. № 52. С. 19-22.

11. Аандіхова А. Образ, зібраний з фрагментів: виставка Олександра Гнилицького в Національному художньому музеї України // Art Ukraine. 2011. № 5 (24). С. 52-55.

12. Аевашов B. URL: http://www.openspase.ru/newa/details/13316/ (Аата обращения: 15.09.2018).

13. Аевашов В., Соловйов О. ОлексанАр Гнилицький. Персональна виставка «Скромність \& Жир»:

Каталог. Київ, 2008. 58 с.

14. Аожкина А., Соловьёв А. Point zero: Новейшая история украинского искусства. Новая волна. Ч. I: 1987-1989 // Top 10. 2010. № 2. С. 45-53.

15. Аожкина А., Соловьёв А. Point zero: Новейшая история украинского искусства. Новая волна. Ч. II: Поколение в зените. 1990-й - середина 1992 года // Тор 10. 2010. № 3. С. 31-39.

16. Аожкина А., Соловьёв А. Point zero: Новейшая история украинского искусства. Новая волна.

Ч. ІІІ: Кето 1990-1994 гоА // Тор 10. 2010. № 4. С. 41-49.

17. Аожкина A., Соловьёв $A$. Point zero: Новейшая история украинского искусства. Ч. IV: СереАина 90-х: Аиалоги с экраном и рожАение грантового сознания // Тор 10. 2010. № 5. С. 45-53.

18. Маньковская Н. Б. Эстетика постмодернизма. Санкт-Петербург: Алетейя, 2000. 348 с.

19. Мизиано В. Аругой и разные. Москва: НАО, 2004. 304 с.

20. Онух $Є$. Сучасне мистецтво дозволяє АюАям віАчути дискомфорт незнання віАповіАі на всі питання // Aura. 2008. № 3-4 (4-5). С. 22-25.

21. Петрова О. М. Третє Око: Мистецькі студії (Монографічна збірка статей). Київ: Фенікс, 2015. 480 c.

22. Ройтбурд A. URL: http://bottega-magazine.com/opinion/read/411/ (Аата обращения: 15.09.2018).

23. Сидоренко В. А. Візуальне мистецтво віА авангардних зрушень до новітніх спрямувань: Розвиток візуального мистецтва України XX-XXI століття. Київ: ВХ[стуАіо], 2008. 188 с.

24. Смирна $\Lambda$. В. Століття нонконформізму в українському візуальному мистецтві. Київ: Фенікс, 2017. 480 c.

25. Соловйов O. I. Турбулентні шлюзи: Збірка статей / Ін-т проблем сучас. мистецтва АМУ. Київ: Інтертехнологія, 2006. $192 \mathrm{c}$.

26. Титаренко О. Семя Оливы: Каталог. Киев, 2010. 24 с. 


\section{References}

1. 25 rokiv pry`sutnosti: Suchasni ukrayins`ki xudozhny`ky` (Katalog). Ky`yiv, 2016. T. 1. 360 c.

2. Avramenko O. Ne vzdumay proschatsya // Art Ukraine. KiYiv, 2009. \# 6 (13). S. 104-109.

3. Aliev A. Aleksandr Gnilitskiy: kto ya, gde ya, kuda ya edu // Unique. Kiev, 2008. \# 10. S. 68-71.

4. Andreeva E. Yu. Postmodernizm. Iskusstvo vtoroy polovinyi XX - nachala XXI veka. S.-Peterburg: Azbuka-klassika, 2007. $488 \mathrm{~s}$.

5. Bayshev O. Bloomsday ‘08, Idealniy vIk: Katalog. KiYiv, 2008. 84 s. 26

6. Burlaka V. P. Istoriya Obrazu: My`stecztvo 2000-x / Fond pidtry`mky`vizual`ny`x doslidzhen`. Ky`yiv, 2011. S. 32-33.

7. Vy`sheslavs`ky`j G. A. «Nova xvy`lya» u vizual`nomu my`stecztvi Ukrayiny` kincya 1980-x pochatku 1990-x (sociokul`turny`j aspekt): Avtoref. dy`s. ... kand. my`stecztvoznavstva: 26.00.01 / In-t problem suchas. my`stecztva NAM Ukrayiny`. Ky`yiv, 2014. $18 \mathrm{~s}$.

8. Gnilitskiy A. http://www.nashizdat.com/blog/magazine/78.html

9. ZhuravlYova L. Hudozhnik Aleksandr Roytburd // Zerkalo nedeli. Kiev, 2009. \# 45. S. 18-22.

10. Zvinyatskovskaya Z. Sozdatel transavangarda // Zerkalo nedeli. Kiev, 1996. \# 52. S. 19-22.

11. Landixova A. Obraz, zibrany`j z fragmentiv: vy`stavka Oleksandra Gny`ly`cz`kogo

v Nacional`nomu xudozhn`omu muzeyi Ukrayiny` // Art Ukraine. Ky`yiv, 2011. \# 5 (24). S. 52-55.

12. Levashov V. http:// www.openspase.ru/newa/details/13316/

13. Levashov V., Solovjov O. Oleksandr Gny`ly`cz`ky`j. Personal`na vy`stavka «Skromnist`\& Zhy`r»: Katalog. Ky`yiv, 2008. 58 s.

14. Lozhkina A., SolovYov A. Point zero: Noveyshaya istoriya ukrainskogo iskusstva. Novaya volna.

Ch. I: 1987-1989 // Tor 10. Kiev, 2010. \# 2. S. 45-53.

15. Lozhkina A., SolovYov A. Point zero: Noveyshaya istoriya ukrainskogo iskusstva. Novaya volna.

Ch. II: Pokolenie v zenite. 1990-y — seredina 1992 goda // Tor 10. Kiev, 2010. \# 3. S. 31-39.

16. Lozhkina A., SolovYov A. Point zero: Noveyshaya istoriya ukrainskogo iskusstva. Novaya volna.

Ch. III: Leto 1990-1994 god // Tor 10. Kiev, 2010. \# 4. S. 41-49.

17. Lozhkina A., SolovYov A. Point zero: Noveyshaya istoriya ukrainskogo iskusstva. Ch. IV: Seredina

90-h: Dialogi s ekranom i rozhdenie grantovogo soznaniya // Tor 10. Kiev, 2010. \# 5. S. 45-53.

18. Mankovskaya N. B. Estetika postmodernizma. S.-Peterburg: Aleteyya, 2000. 348 s.

19. Miziano V. Drugoy i raznyie. Moskva: NLO, 2004. 304 s.

20. Onux Ye. Suchasne my`stecztvo dozvolyaye lyudyam vidchuty` dy`skomfort neznannya vidpovidi na vsi py`tannya // Aura. Ky`yiv, 2008. \# 3-4 (4-5). S. 22-25.

21. Petrova O. M. Tretye Oko: My`stecz`ki studiyi (Monografichna zbirka statej). Ky`yiv: Feniks, 2015. $480 \mathrm{~s}$.

22. Roytburd A. http://bottega-magazine.com/opinion/read/411/

23. Sy`dorenko V. D. Vizual`ne my`stecztvo vid avangardny`x zrushen` do novitnix spryamuvan`: Rozvy`tok vizual`nogo my`stecztva Ukrayiny`XX-XXI stolittya. Ky`yiv: VX[studio], 2008. 188 s.

24. Smy`rna L. V. Stolittya nonkonformizmu v ukrayins`komu vizual`nomu my`stecztvi. Ky`yiv: Feniks, 2017. $480 \mathrm{~s}$.

25. Solovjov O. I. Turbulentni shlyuzy`: Zbirka statej / In-t problem suchas. my`stecztva AMU. Ky`yiv: Intertexnologiya, 2006. $192 \mathrm{~s}$.

26. Titarenko O. Semya Olivyi: Katalog. Kiev, 2010. 24 s. 27 


\section{Абрамович И. В. Александр Гнимицкий на «Новой волне»: Художник в конце 1980-х - начахе 1990-х}

Аннотация. Рассмотрен ранний этап творчества украинского художника Александра Гнилицкого (1961-2009). Показано, что его произведения следует рассматривать в тесной связи с историко-бытовым контекстом, учитывая обстоятельства, время, социальную и творческую среду. Отмечено, что ранний этап творчества, а впоследствии и окончательное формирование Гнилицкого как художника произошии в переломные времена в истории Украины, - когда устоявшиеся каноны живописи, прописанные советским тоталитарным режимом, оказываются архаичными и подвергаются сокрушительному сомнению со стороны молодого поколения художников. Подчеркнуто, что произведениям Гнилицкого рассматриваемого периода присущи субъективизм, цитатность, самоирония, циничное переосмысление китературных сюжетов, использование приёмов гротеска, мотивов макабрической эротики. На выбранном Аля обработки материале был осуществлён историко-культурный и искусствоведческий анализ

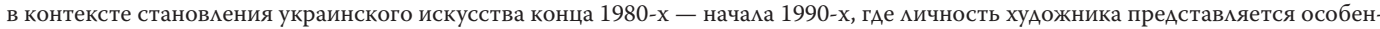
но уместной, поскольку символизирует собой специфику этого искусства: от неожиАанности к эпатажу, от сложности к гротеску, от неподкупности к отчаянию и даже кощунству. САелана попытка показать всю неподАельную, героическую жертвенность настоящего мастера. Это представцяется особенно красноречивым в отношении искусства именно современного, принципиальная самооценка которого зафиксирована в суждениях и высказываниях его представителей. Общая картина жизни и творчества Гнилицкого, его Аичность идеально укладываются в тот идеал или, скорее, норматив «авангарда», Аля которого существуют определения и художественное, и философское. На примере анализа произведений художника показано, в частности, его творческое формирование в контексте направления «Новая волна» и группировки «Парижская коммуна».

Ключевые слова: искусство Украины 1980-1990-х, творчество Александра Гнилицкого, «Новая волна», группировка «Парижская коммуна», живопись, инстамляция.

\section{Абрамович I. В. ОмексанАр Гнимицький на «Новій хвимі»: Художник наприкінці 1980-х - на початку 1990-х}

Анотація. Розгяянуто ранній етап творчості українського художника Олександра Гнилицького (1961-2009). Показано, що його твори необхіАно розгляАати у найтіснішому зв'язку з побутово-історичним контекстом: обставини, час, соціальне й творче середовище. Зазначено, що ранній етап творчості, а згодом й остаточне формування Гнилицького як митця припадають на зламні часи в історії України: на час, коли усталені канони живопису, прописані радянським тоталітарним режимом, виявляються архаїчними та підАаються нищівному сумніву молодого покоління художників. ПіАкреслено, що творам Гнилицького розглянутого періоду притаманні суб'єктивізм, цитатність, самоіронія, цинічне переосмислення мітературних сюжетів, використання прийомів гротеску, мотивів макабричної еротики. На обраному Аля опрацювання матеріалі був здійснений історико-культурний й мистецтвознавчий аналіз в контексті становмення українського мистецтва кінця 1980-х - початку 1990-х, через що постать художника видається особливо доречною, ніби символізуючи собою власну специфіку цього мистецтва: від несподіваності до епатажу, віА скмадності до гротеску, віА непіАкупності до відчаю й блюзнірства. Зроблено спробу показати всю непіАробну, героїчну жертовність справжнього художника. Це виАається особливо красномовним стосовно мистецтва саме сучасного, принципову самооцінку якого зафіксовано у судженнях і висловах його преАставників. Загальна картина життя і творчості Гнилицького, його постать ідеально вкцадаються у той ідеал чи радше норматив «авангарду», що йому вже існує формулювання і художнє, й філософське. На прикцаді анацізу творів художника показано, зокрема, його творче формування в контексті напряму «Нова хвиця» та угруповання «Паризька комуна».

Ключові слова: мистецтво України 1980-1990-х, творчість Олександра Гнилицького, «Нова хвиля», угруповання «Паризька комуна», живопис, інсталяція. 